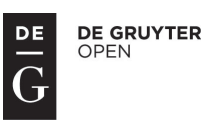

\title{
GaAR as Tax Treaty OVerRide - Slovak Perspective
}

\author{
Andrea Koroncziová ${ }^{1}$, Matej Kačaljak ${ }^{2}$
}

\begin{abstract}
The article summarises the views on the interrelation of GAARs and tax treaties, abstracts defining criteria for the feasibility of GAAR as an anti-abuse instrument in tax treaty situations and applies these to the situation (legislation and case law) in the Slovak Republic. The aim of the article is to provide insight on the potential interrelation of GAAR rules with existing tax treaties and formulate policy advice that should be optimal given the facts at hand. It shows that GAAR in its current form would in general have limited effectiveness in tackling tax treaty abuse situations without it resulting in treaty override. This particularly applies to the Slovak Republic and likely to other states applying a monistic approach to international treaties, where the renegotiation of the treaty seems the only viable option. However, as in Slovakia the monist approach applies only to treaties ratified after July 2001, a different approach might be taken with respect to those that are still subject to a dualist approach.
\end{abstract}

\section{Keywords}

GAAR, Treaty Override, Slovak Republic, Monistic Approach, Tax Treaty

\section{Introduction}

General anti-avoidance rules or general anti-abuse rules (as applicable) ("GAARs") have recently become a relatively common element of tax systems around the world though they "have played a central role in other tax systems for well over a century", 3 , e.g. New Zealand, which has had a GAAR for 139 years. Similarly, the issue of treaty override has also "been a concern since the first tax treaties were drafted". 4 The focus of this article is to examine the potential for the effective use of GAAR in the Slovak Republic

\footnotetext{
${ }^{1}$ Comenius University of Bratislava, Faculty of Law, Department of Financial Law, Šafárikovo nám. 6, P.O. Box 313, 81000 Bratislava, Slovak Republic. E-mail: andrea.koroncziova@flaw.uniba.sk.

${ }^{2}$ Comenius University of Bratislava, Faculty of Law, Department of Financial Law, Šafárikovo nám. 6, P.O. Box 313, 81000 Bratislava, Slovak Republic. E-mail: matej.kacaljak@flaw.uniba.sk.

3 Krever (2016).

${ }^{4}$ Kulcsár (2013) For an up to date list of literature on the topic, see Mikic (2013).
} 
as an instrument to prevent tax treaty abuse and whether this would result in a tax treaty override. The aim of the article is to provide insight on the potential interrelation of GAARs with existing tax treaties and formulate policy advice that should be optimal given the facts at hand. The article adds new context to an expanding corpus of works dealing with this topic..$^{5}$ The content of the article is topical due to the revived debates over the applicability of GAARs in tax treaty situations ${ }^{6}$, which, with some delay, have also reached scholars and practitioners in Central and Eastern Europe. Finally, the article provides new context to these debates, as it deals with relatively recent decisions of the Slovak Supreme Court, which have indicated what would likely be the approach of courts in continental jurisdictions in treaty abuse situations where the treaty itself does not contain anti-abuse measures.

\section{Relevant concepts}

\section{GAAR}

A general anti-avoidance rule (GAAR) is defined as "an anti-avoidance measure, generally statute based, providing criteria of general application, i.e. not aimed at specific taxpayers or transactions, to combat situations of perceived tax avoidance". ${ }^{7}$ GAAR is considered a rule which "empowers the taxing authority to impose tax on the basis of the outcome of the transaction or events when the tax avoidance components of the arrangements are disregarded, i.e. by adopting a substance over form approach". 8 GAARs have been described as "the only way to plug gaps discovered by ingenious tax consultants", as they "should be broad enough to catch tax avoidance schemes not yet contemplated by the drafter of the GAAR". ${ }^{10}$ They are considered necessary to ensure that the tax base is not minimized ${ }^{11}$ due to "the failure of the legislature to keep pace with newly emerging tax avoidance schemes" ", as well as "to prevent abusive arrangements that are not adequately dealt with through specific rules or judicial doctrines"13. Thus, GAARs are considered "a sort of catch-all provisions for tax avoidance schemes". ${ }^{14}$ These GAARs are present in the national tax systems of many states and can be expressly incorporated in the tax codes or exist in a form of general principle of abuse of law developed by national judges via national case law. ${ }^{15}$

\footnotetext{
${ }^{5}$ For a comprehensive overview of various countries' approaches, see the country reports in Staringer, C. (2016), though it should be noted that not all reports deal with the issue in detail (e.g. the Slovak report). For a discussion of the interrelation between GAARs and tax treaties, see further Kulcsár (2012).

${ }^{6}$ Kulcsár (2013).

${ }^{7}$ Larking (2005).

${ }^{8}$ Holmes (2014).

${ }^{9}$ Murray (2012).

${ }^{10}$ Cotrut (2015).

11 Ibid.

12 Tooma (2008).

${ }^{13}$ United Nations Model Double Taxation Convention between Developed and Developing Countries: Commentary on Article 1.

${ }^{14}$ Cotrut (2015).

15 Russo (2010).
} 
So, in essence, tax avoidance arrangements can be countered in two ways: ${ }^{16}$ (A) by relying on judicial doctrines which do not need to be incorporated in the legislation or (B) by passing new legislation. Further, the courts can counter the tax avoidance with two judicial approaches: abuse of law doctrine/principle (the doctrine is adopted in cases where no statutory anti-avoidance provision exists or exists just in a very broad wording) used mainly by civil law countries and substance over form used by the majority of common law countries.

Within the EU context, the European Commission has already made a recommendation that "Member States should adopt [into their national legislation] a general anti-abuse rule to counteract aggressive tax planning practices which fall outside the scope of their specific anti-avoidance rules" 17 with the following wording: "An artificial arrangement or an artificial series of arrangements which has been put into place for the essential purpose of avoiding taxation and leads to a tax benefit shall be ignored. National authorities shall treat these arrangements for tax purposes by reference to their economic substance." 18

The Slovak GAAR reads as follows "legal acts or other facts decisive for establishing, assessing or collecting tax which do not have an economic reason and resulting in intentional circumvention of tax liability, or obtaining such benefit that otherwise would not be obtained, or resulting in intentional reduction of tax liability, shall be disregarded in the administration of taxes". ${ }^{19}$ According to some, the Slovak GAAR may also be applicable to cross-border situations. ${ }^{20}$ Nevertheless, the interrelation between a Slovak GAAR and tax treaties entered into by the Slovak Republic has not yet been discussed by legal scholars.

\section{Treaty Override}

The "tax treaty override" is partly addressed in a 1989 OECD report ${ }^{21}$ and "refers to a situation where the domestic legislation of a state overrules provisions of either a single treaty or all treaties hitherto having had effect in that State. Legislation may take the form of a provision that treaty provisions are to be disregarded in certain circumstances (e.g. in cases of treaty shopping or other forms of abuse). Legislation can also have the effect of overriding treaties, even where no reference is made in the legislation to treaty provisions as such, because the domestic interpretation of the effect of that legislation in relation to treaty provisions has the same effect in practice." The respective situation nevertheless represents only a segment of the treaty override situations and international organisations have yet to provide an exact general definition ${ }^{22}$.

As an example, the 1989 OECD report referred to the following additional situations that "either involve or are similar to treaty override and may have the same effects":

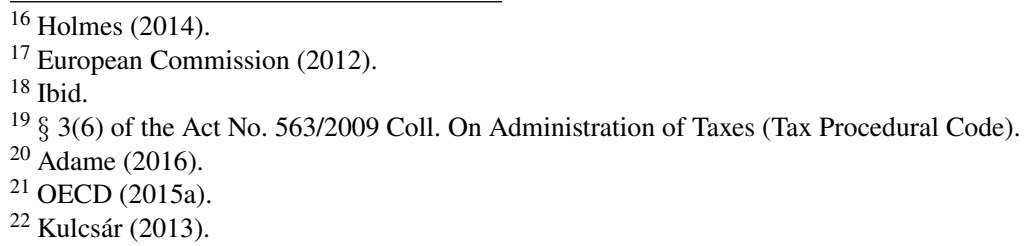


a) legislation reversing (the effect of) a court decision that deviates from the common interpretation of a treaty, explicitly accepted or tacitly implied by the treaty partners; where, however, OECD notes that "it is not considered that any injury is done to the basis of international tax relations if the competent legislative and administrative organs of the states concerned are in agreement that the court decision is contrary to their intentions [and] it is the court's decision in the first place [...] overriding the treaty";

b) change in the definition of a term used in domestic legislation and also used in treaty provisions, but not specifically defined for the purposes of the treaty; according to OECD, "there is no override where the treaty contains a provision [providing that] any term not defined in the treaty shall, unless the context otherwise requires, have the meaning which it has under the law of that state concerning the taxes to which the treaty applies [and] it cannot have been contemplated that, having once entered into a treaty, a state would be unable to change definitions of terms used in its domestic law provided such changes were compatible with the context of the treaty" 23 that having said it should be observed that if a state "abuses its discretion to develop a proper, domestic terminology for tax purposes, and artificially construes the terms of a tax treaty with the aim or the effect of seriously altering the equitable distribution of tax revenue, it fails to carry out the treaty in good faith" 24 ; and

c) newly adopted domestic legislation being incompatible with a treaty provision, without the competent organs intending, or even being aware of, such an effect. ${ }^{25}$

As such, invariably of the legitimacy of the objectives pursued (e.g. to counteract the abuse of conventions), under the position of OECD the tax treaty override should be avoided. ${ }^{26}$ In general, the reasons to avoid a tax treaty override come primarily from international law, but may also stem from local law.

\section{International law aspects of treaty override}

Tax treaties belong in the sphere of international law and, as such, are governed, among others, by the rules of the Vienna Convention (1969) ${ }^{27}$ A "treaty" in the Vienna Convention (1969) is defined as "an international agreement concluded between States in written form and governed by international law, whether embodied in a single instrument or in two or more related instruments and whatever its particular designation". With the absence of any derogation with respect to tax treaties, the Vienna Convention (1969) should apply to all tax treaties entered into between its members after its entry into force with regard to

\footnotetext{
${ }^{23}$ All the double tax treaties entered into by the Slovak Republic contain such provision - except for the double tax treaty concluded with Mongolia.

${ }^{24}$ Maisto (2006) For further discussion on the good faith interpretation of tax treaty, see below.

25 See further below for discussion of the Slovak perspective.

26 OECD (2015a).

27 Vienna Convention on the law of treaties concluded at Vienna on 23 May 1969. As a successor state of Czechoslovakia, the Slovak Republic has been bound by the Vienna Convention since 28 August 1987.
} 
such states. ${ }^{28}$ "As regards tax treaties between states that are not parties to the Convention or tax treaties that were concluded prior to the entry into force of the Convention [its] principles may be applicable as [it] codifies the rules of customary international law."29 In particular, Articles 26 and 27 stand out in this respect. Article 26 embodies the pacta sunt servanda principle and reads: "Every treaty in force is binding upon the parties to it and must be performed by them in good faith". Further, Article 27 reads that "A party may not invoke the provisions of its internal law as justification for its failure to perform a treaty”.

Therefore, "treaty override by way of application of domestic legislation or interpretation of such legislation leading to failure to perform a treaty, in principle, constitutes a breach of states' obligations under international law, regardless of the permissibility of such an override under domestic law". ${ }^{30}$ For completeness, despite some scholars' opinions that treaty override is incompatible with the EU loyalty principle, the Court of Justice of the European Union has been unwilling to address the tax treaty override in its judgements, taking the position that it is "incompetent to rule on the relationship between a domestic provision and a tax treaty". 31

It merely needs to be established whether the above may be regarded as an interpretation of the treaty in line with the rules on interpretation of treaties as contained in Articles 31 to 33 of the Vienna Convention (1969), whereby a conclusion might be reached that the new domestic legislation or its interpretation are in fact not in conflict with the original treaty provision if properly interpreted (i.e. the so called "interpretation approach") ${ }^{32}$ In other words, the respective state would establish that combating tax avoidance is one of the primary objectives of a tax treaty and, therefore, "pacta sunt servanda does not prevent states from overriding positive tax treaty obligations and relying on domestic law to serve this object and purpose of the treaty. On the contrary, based on this understanding of pacta sunt servanda, it could be said that states are, to some extent, obliged to act against avoidance in relation to tax treaties. Failure to prevent tax treaty abuse could, in this regard, even be perceived as a violation of the obligation not to defeat the object and purpose of the tax treaty." 33

Assuming this extensive interpretation of pacta sunt servanda principle is given relevance by the courts ${ }^{34}$, it still needs to be established whether the prevention of tax treaty abuse is in fact the object and purpose of the tax treaty. Such identification is not simple. ${ }^{35}$ Therefore, though as of 2003, paragraph 7 of the OECD Commentary to the Model Tax Convention provides that "the principal purpose of double taxation conventions is to promote, by eliminating double taxation, exchanges of goods and services, and the

\footnotetext{
${ }^{28}$ Article 4 of the Vienna Convention (1969).

${ }^{29}$ Gerzova (2013). See also Maisto (2006).

${ }^{30}$ Gerzova (2013).

31 Offermanns (2013).

32 Michel (2013).

33 Ibid.

${ }^{34}$ In the doctrine, it is commonly accepted, however, that this very expansive interpretation of the principle of pacta sunt servanda has only limited relevance. See further Michel (2013).

35 Zemanek (1998).
} 
movement of capital and persons" and that "it is also a purpose of tax conventions to prevent tax avoidance and evasion", there are doubts as to whether this may be considered a reliable indicator of the object and purpose of a particular tax treaty. ${ }^{36}$

Firstly, the OECD Commentary is only one of the sources of interpretation for tax treaties amongst other sources (including the "object \& purpose of a treaty" itself). It then "seems illogical that one source of interpretation (i.e. the OECD Model: Commentary) can determine the content of another source of interpretation (i.e. 'interpretation ... in light of a treaty's object and purpose' as mentioned in article 31(1) of the Vienna Convention (1969)) and determine the application of all (7) other articles of the Vienna Convention that refer to 'object and purpose. At least one should be able to establish that anti-avoidance is a tax treaty purpose based on analysis of the tax treaty itself and without relying on the OECD Model: Commentary to this extent." ${ }^{37}$ In short, unless there is a clear indication in the text of the tax treaty (including the preamble), one would find it difficult to concur with the clear statement in the OECD Commentary. It also needs to be clarified that although, as proposed by the Commentary, a number of treaties may include in their title a reference to "either the avoidance of double taxation or both the avoidance of double taxation and the prevention of fiscal evasion [...] it is generally accepted that the prevention of fiscal evasion is not identical to the prevention of tax avoidance" ${ }^{38}$ The same would then apply to the use of preambles for treaty interpretation, if such would merely reiterate the title of the treaty. Clearly, no new context could be derived from an identical wording, but placed elsewhere in the treaty.

Further, another issue arises from the fact that up until the 2003 changes, paragraph 7 of the Commentary on Article 1 of the OECD Model read that, although "tax treaties should not help tax avoidance and evasion [...] it is for states to preserve in their tax treaties the application of domestic rules countering such practices". The position in the Commentary has shifted significantly in 2003 and, even assuming the Commentary could hold by itself as a source of interpretation of a tax treaty, the results would vary greatly with respect to treaties entered into before this date in dependence of choice of static v. ambulatory interpretation approach. ${ }^{39}$ The static approach would then lead to a clear conclusion that the "prevention of tax avoidance and evasion" as an object and purpose may not be derived from the OECD Commentary with respect to tax treaties entered into before 28 January 2003. The official OECD position is that the current Commentary should be used to interpret all treaties. ${ }^{40}$ However, the prevailing view of commentators "seems to be that static interpretation, i.e. interpretation by reference to the Commentary prevailing at the time the treaty was concluded, is the starting point". ${ }^{4}$

Ambiguous references in the commentary do not automatically result in rejection of the hypothesis that the prevention of tax treaty abuse is the object and purpose of the tax treaty.

\footnotetext{
${ }^{36}$ Maisto (2006).

${ }^{37}$ Michel (2013).

${ }^{38}$ Michel (2013).

${ }^{39}$ Wattel (2003).

${ }^{40}$ Paras. 33-35 of the Introduction to the OECD Model Tax Convention (2014).

${ }^{41}$ Maisto (2006).
} 
However, other historical observations also show that there has been a rather drastic change in this respect. In the 1986 Conduit Report, the OECD Committee on Fiscal Affairs (rather bluntly) opined that "Existing conventions may have clauses with safeguards against the improper use of their provisions. Where no such provisions exist, treaty benefits will have to be granted under the principle of 'pacta sunt servanda' even if considered to be improper." 42 Further, the Committee held that in the event of such improper use, the contracting states should "remedy the situation by adequately revising the treaty". ${ }^{43}$ This implies that, at least at some point of time, there was a relative consensus that the treaty abuse should be dealt with by revising the text of the treaty rather than by updating its interpretation to a new context (which arguably did not exist at the time of conclusion of the treaty). This problem, in our view, is stronger in statutory law jurisdictions where it is expected that the legislator will react to changes and not find "new interpretations" ex post.

Nevertheless, as the set of available remedies under international law is relatively limited (the suspension or termination of the tax treaty being one of them) ${ }^{44}$, it seems more likely with respect to treaty override aimed at prevention of treaty abuse that the treaty states will engage in a dialogue aimed at the inclusion of anti-avoidance provisions in their tax treaties. At the same time, it may not be entirely excluded that they would tacitly (likely upon mutual consultation) tolerate treaty override in treaty abuse cases.

\section{Local law aspects of treaty override}

The approach of states to treaty override varies greatly even within the OECD member states. ${ }^{45}$ The interaction between domestic law and international law depends on the constitutional order of particular states. ${ }^{46}$ While in states adhering to the dualistic approach it is more likely that a treaty override would be found in line with their legal principles ${ }^{47}$, in states applying the monistic approach with clearly defined precedence of international treaties before local law provisions any provisions of local laws or a judicial practice would be found unconstitutional per se. ${ }^{48}$

As an example, the United States of America overrides its treaties based on the lex posterior derogat legi priori principle embedded in legislation and judicial practice. ${ }^{49}$ Similarly, relatively recently the Federal Court of Germany held that the treaty override is constitutional. ${ }^{50}$

\footnotetext{
${ }^{42}$ OECD (2015b).

${ }^{43}$ Ibid.

${ }^{44}$ Gerzova (2013). See also Maisto (2006).

${ }^{45}$ For illustration, consult the observations of states to the OECD Commentary to Article 1 of the OECD Model

Tax Convention OECD (2015).

${ }^{46}$ Sachdeva (2013).

${ }^{47}$ International law consequences are not taken into account for this part of the analysis.

${ }^{48}$ For discussion of monism and dualism, see further Aust (2013).

${ }^{49}$ Gerzova (2013). See also Maisto (2006).

${ }^{50}$ Cloer (2016).
} 
On the other hand, in states where the precedence of international treaties ${ }^{51}$ is clearly stated in their constitutions, neither the legislator nor the courts have the power to ignore (or reverse) this order even if the circumstances might justify such an approach.

\section{GAAR and treaty override}

Opinions differ on the question of whether domestic anti abuse rules (i.e. not only GAAR) $)^{52}$ may apply in tax treaty situations.

As of 2003, the OECD Commentary specifies that "as a general rule, there is no conflict between tax treaties and domestic general anti-abuse measures". ${ }^{53}$ In particular, the OECD Commentary reads that "other forms of abuse of tax treaties (e.g. the use of a base company) and possible ways to deal with them, including 'substance-over-form', 'economic substance' and general anti-abuse rules have also been analysed, particularly as concerns the question of whether these rules conflict with tax treaties" 54 and that "such rules are part of the basic domestic rules set by domestic tax laws for determining which facts give rise to a tax liability; these rules are not addressed in tax treaties and are therefore not affected by them". ${ }^{55}$ Nevertheless, the OECD Commentary concludes that "whilst these rules do not conflict with tax conventions, there is agreement that member countries should carefully observe the specific obligations enshrined in tax treaties to relieve double taxation as long as there is no clear evidence that the treaties are being abused". ${ }^{56}$ The interpretation that domestic anti-abuse rules stand only for rules for determining which facts give rise to a tax liability is shared by several tax administrations. ${ }^{57}$

On the other hand, according to Lang, domestic anti-abuse legislation does not apply to treaty benefits, as "when domestic anti-abuse rules apply to extend the taxable basis, the treaty protection still exists. [Tax treaties] set out the situations in which the domestic right to tax is reduced, eliminated or maintained. This function would be lost if it were to be interpreted by reference to domestic anti-abuse rules." ${ }^{, 5}$ Lang further adds that "if the tax authorities of each contracting state interpreted a provision of a /tax treaty/ in the light of its own domestic anti-abuse rules, it would lead to two different interpretations of the provision because anti-abuse rules differ from country to country. This is not in line with the object and purpose of /tax treaties/." 59

\footnotetext{
${ }^{51}$ For example, the Czech Republic and the Slovak Republic, Greece, Spain, Croatia. See further Maisto (2006).

${ }^{52}$ The anti abuse rules comprise, in addition to a GAAR, a "substance over form" rule disregarding the legal form of a transaction in favour of its true economic substance (e.g. in the US), or a general prohibition against the abuse of law ("fraus legis") (e.g. in Austria, France, Germany, the Netherlands, Spain, Sweden, and Switzerland). See further Vogel (1997), p. 117.

${ }^{53}$ Gerzova (2013).

${ }^{54}$ Para. 22 OECD Model: Commentary on Article 1, OECD (2015).

55 Para. 22.1 OECD Model: Commentary on Article 1, OECD (2015).

${ }^{56}$ Para. 22.2 OECD Model: Commentary on Article 1, OECD (2015).

${ }^{57}$ E.g. the New Zealand "Inland Revenue's view is that a DTA does not prevent the GAAR or a SAAR from applying. In Inland Revenue's view, the GAAR should first be applied to establish the relevant fact situation. New Zealand's domestic tax law and the DTA then apply to that recharacterised fact situation". See New Zealand Inland Revenue (2016).

${ }^{58}$ Lang (2014), chapter 5.2.

${ }^{59}$ Ibid.
} 
Clearly, the above different approach stems from the understanding of "determination of facts giving rise to a tax liability". It seems that the view of the OECD Commentary is that the facts are objective and could not be assessed differently by different tax authorities. As will be illustrated below, this is not always the case and the application of a domestic anti-abuse rule may amount to treaty override.

In example 1, a company tax resident in state A ("Company A") is paying out interest income to a company tax resident in state B ("Company B"). As there is no tax treaty between states $\mathrm{A}$ and $\mathrm{B}$, a fictional company resident in state $\mathrm{C}$ is interposed between $\mathrm{A}$ and B. State $\mathrm{C}$ has a tax treaty with both state $\mathrm{A}$ and state $\mathrm{B}$ and the tax treaties are based on the OECD Model $2003^{60}$. The company may be either entirely non-existent or may in fact have necessary substance, but its involvement in the structure is entirely fictional, i.e. it was not in any way involved in the transaction or even did not have any knowledge of its involvement. As such structure is entirely fictional, there is, indeed, no cross-border element and, thus, there is no ground for tax treaty application. However, we are of the view that such situations are extremely rare and amount to most aggressive frauds where there should be other elements present on which their proprietors rely than an effective tax treaty protection.

Example 2 involves a situation identical to that in example 1, but with a conduit company established by the Company B in state C ("Company C"). This company is involved in the transaction but it may occur that its tax residency in state $\mathrm{C}$ is based on the registered seat criterion, while under the place of effective management criterion it would be considered a tax resident of state B. In other words, if an anti-abuse rule is applied to establish the fact, any tax authority would have to come to the same conclusion that Company $\mathrm{C}$ has its place of effective management in state B. Nevertheless, for the purposes of the tax treaty between state $\mathrm{A}$ and state $\mathrm{C}$, Company $\mathrm{C}$ is considered a tax resident of state $\mathrm{C}$ as the place of effective management tie-breaker rule would apply only if the Company $\mathrm{C}$ is considered a tax resident of both state $\mathrm{A}$ and $\mathrm{C}^{61}$. A domestic anti-avoidance rule (such as GAAR) would, however, force the tax administration of state A to regard the transaction as a transaction between tax residents of state $\mathrm{A}$ and $\mathrm{B}$ and, thus, disregard the tax treaty between states $\mathrm{A}$ and $\mathrm{C} .{ }^{62}$ This is clearly not an objective fact, but a legal fiction imposed on the tax administration of state A by a local rule of state A, which amounts to a treaty override.

The same would apply to example 3 , in which Company $\mathrm{C}$ would pass the necessary substance tests and would be regarded as a tax resident of state $\mathrm{C}$ both under the registered seat and the place of effective management criterion. The structure as a whole would, however, be considered abusive under the principal purpose test imposed by a domestic anti-abuse rule. In such case, Company $\mathrm{C}$ would be disregarded not as a result of it being

\footnotetext{
${ }^{60}$ OECD (2003).

${ }^{61}$ See OECD (2003) Article 4 para. 1 and 3.

${ }^{62}$ Different conclusions may, however, stem from a tax treaty entered into after 2008, when para. 8.2 of the Para. 22 OECD Model: Commentary on Article 4 could be theoretically taken into account when interpreting the tax treaty. There may also be situations when a domestic rule would (somewhat counter-intuitively) deny a tax residence of a tax payer if such taxpayer is considered a tax resident under a tie-breaker rule in some tax treaty in force. For further discussion of the issue, see Sasseville (2006).
} 
non-existent or not fulfilling the (e.g. residency) criteria for treaty protection (i.e. due to facts), but due to a legal fiction construed by local law and overriding the tax treaty. Taking into account the fact that (unless agreed in a tax treaty ${ }^{63}$ ) taxpayer's purpose tests, being standard parts of GAARs, differ greatly across countries ${ }^{64}$, we would concur with the reasoning of Lang cited above. It should be noted that it is likely that a majority of treaty abuse occurrences would fall within the category represented by this example 3 .

Examples 2 and 3 above would clearly amount to treaty override where, as indicated earlier, severe international law and domestic law consequences may arise. Accordingly, the approach of states varies. E.g. in the UK, although "GAAR can be applied to counteract the abusive arrangements", this clearly "does not mean that the domestic GAAR can override tax treaties". ${ }^{65}$ On the other hand, notable examples of states where fight against abuse is considered a justifiable cause even for treaty override include Austria, Canada, and Germany. ${ }^{66}$

We would concur with the position that "the application of domestic anti-avoidance rules [...] in relation to tax treaties is not in line with the principle of pacta sunt servanda and should rightfully be considered as a 'treaty override', with all the reputational damage this entails". 67

\section{Slovak Republic}

In further text, the above general considerations will be applied to the Slovak legislative and judicial context.

\section{Monistic approach to international law with priority of international treaty}

The relationship between national law and international law varies from state to state. Below, the position of the Slovak Republic will be described with the use of standard differentiation into: 1 . Monistic theory with supremacy of national law, 2. Dualistic theory, 3. Monistic theory with supremacy of international law (based on the principle pacta sund servanda) ${ }^{68}$.

The influence of dualistic theory prevailed within the territory of the Slovak Republic until the amendment of Act No. 460/1992 Coll. - the Constitution of the Slovak Republic in 2001. This amendment brought a change in favour of monistic theory with primacy of international law due to, among others, the insertion of Art. 1 para. 2 into the Constitution, which reads: "The Slovak Republic recognizes and honors general rules of international law, international treaties by which it is bound and its other international obligations." Other provisions of the Constitution are also influenced by this abovementioned provision. In particular, the explicit expression of the pacta sund servanda principle in Article 7 para.

\footnotetext{
${ }^{63}$ For the purposes of this article, it is generally presumed that no such agreements are in place.

${ }^{64}$ Krever (2016).

${ }^{65}$ Freedman (2016).

${ }^{66}$ Gerzova (2013).

${ }^{67}$ Michel (2013).

${ }^{68}$ Aust (2013), Sachdeva (2013) In the Slovak literature, see e.g. Ottová (2006) or most recently in the tax treaty context, Kubicová (2016).
} 
2 of the Constitution of the Slovak Republic reads "Legally binding acts of the European Communities and of the European Union shall have precedence over laws of the Slovak Republic" and presents the monistic approach with primacy of acquis communitaire over Slovak national law due to the accession of the Slovak Republic to the European Union. Finally, the monistic approach can also be seen in Article 7 para. 5 of the Constitution of the Slovak Republic, which reads "International treaties [...] which were ratified and promulgated in the way laid down by a law shall have precedence over laws". However, this provision "has an 'ex-nunc effect' because it applies to self-executing treaties ratified after the Constitutional Act No 90/2001 came into effect, making these treaties directly applicable in domestic law".

As far as the international treaties ratified and promulgated prior to the Constitutional Act No 90/2001 are concerned, a soft dualist approach has been preserved. ${ }^{69}$ This is due to the transitory provision of Article 154c para. 2 of the Constitution of the Slovak Republic, which reads that "Other international treaties which the Slovak Republic has ratified and were promulgated in the manner laid down by a law before taking effect of this constitutional act, shall be a part of its legal order, if so provided by a law”.

The double tax treaties belong to the category of treaties which prevail over the national legislation according to the abovementioned provisions of the Constitution but also according to Section 1 para. 2 of the Act No. 595/2003 Coll. on Income Tax and Section 162 of the Act No. 563/2009 Coll. on Administration of Taxes (Tax Procedural Code).

However, their position would be different depending on whether they were ratified and promulgated (A) before 1 July 2001 (where the soft dualist approach would apply and their precedence over national law would stem from provisions in Act on Income Tax and Act on Administration of Taxes referred to above); or (B) on or after 1 July 2001 (where the monist approach would apply and their precedence over national law would stem directly from the Constitution).

\section{Static interpretation approach to OECD Commentary}

Though there is no dispute pending before the Slovak courts on the relationship between Slovak GAAR and tax treaties, the Supreme Court of the Slovak Republic has ruled relatively recently on the issue of application of OECD Commentary ${ }^{70}$ Although the court did not make explicit its inclination towards the static approach, it did voice its objections against the ambulatory interpretation as presented in the Introduction to the OECD Model Tax Convention on Income and on Capital (2003), para. $35^{71}$. However, it did explicitly state that in the context of "written law jurisdictions where the state organs may act only within the boundaries of Constitution and Acts of parliament, which doubtless includes the Slovak Republic, decisions on the change of content of international treaties and their impact may not be transferred to an institution - OECD and its Committee on Fiscal Affairs". ${ }^{2}$ Further, the court expanded on this by adding that neither the OECD Model

\footnotetext{
${ }^{69}$ Lantajová (2011).

${ }^{70}$ Slovak Supreme Court (2015) For more on the circumstances of the case and decision preceding the decision of the Supreme Court of the Slovak Republic case, see Blahova (2014).

${ }^{71}$ The court cited from Jimenéz (2004), Bothe (1980) and Snyder (1994).

${ }^{72}$ Slovak Supreme Court (2015).
} 
Tax Convention on Income and on Capital or any of the commentaries thereto have been published in the Slovak Collection of Acts, which is a statutory prerequisite for application of assumption of general publicity and of the ignorantia legis non excusat principle.

The court has thus clarified its position in the previous decision on the same issue where it observed that "new wording of provisions of OECD Model tax treaty and its Commentary are applicable also to double tax treaties concluded before this change if the two following conditions are fulfilled cumulatively: 1. the member states do not make a reservation against the new wording and 2. the aim of this change is merely to clarify the meaning of relevant provisions and not to change them" and "if the revision or amendment of the OECD Model tax treaty or its Commentary change the original text of the relevant provision to such extent that it is not just a clarification, or if it creates new definition not present in the initial or revised version of the bilateral double tax treaty, this new meaning could be applicable to the specific case before the court only if a corresponding amendment is made also to the text of the bilateral double tax treaty."73 This indicates that the court would likely be sceptical to argumentation that tax treaty abuse is the object and purpose of the tax treaty if this is neither clear from the text of the tax treaty nor was there a clear consensus on the issue at the time of entering into the treaty (i.e. arguably with respect to most of the treaties entered into before January 2003).

It should, however, be noted that the court missed the opportunity to also elaborate on the topic of abuse of the tax treaty (as from the circumstances of the case it seems that there arguably was an abuse present) from an international law perspective. This may be partly due to the fact that the Slovak Tax Administration did not focus on this aspect and apart from a general declaration of existence of abuse of the treaty it did not expand on its reasoning. Instead it focused on the issue of application of OECD Commentary.

\section{Catalogue of old treaties}

There are currently 65 tax treaties in force in the Slovak Republic. Out of these treaties, 47 were entered into before January 2003, i.e. before the date OECD dramatically changed its approach to abuse of tax treaties.

Although out of all tax treaties 50 (out of which 31 were entered into before January 2003) contain in their title an explicit statement that their purpose is the prevention of fiscal/tax evasion (which corresponds to the common practice recommended also by the OECD, see further above), none contains any reference to the treaty abuse.

A number of treaties contains anti-avoidance measures where "the contracting states agree between themselves that relief offered by the double tax treaties from domestic tax obligations will not apply in certain cases. These measures vary from double tax treaty to double tax treaty." 74 Specifically, the double tax treaties of the Slovak Republic with the USA (1994), Poland (1996, Protocol in 2014), Cyprus (1981) and Israel (2000) contain the limitation on benefits clause (in the treaty with Cyprus it is called limitation on tax relief clause) as a provision which stipulates conditions for granting tax relief and as a provision which stipulates conditions for granting tax relief and as a provision according

\footnotetext{
73 Slovak Supreme Court (2012).

${ }^{74}$ Holmes (2014).
} 
to which benefits resulting from the treaty in question will not apply, if the income is paid or accruing in connection with the artificial constructions or contrary to the purpose of the treaty. ${ }^{75}$ These provisions should in essence have the same effect as the Slovak GAAR but, most importantly, without resulting in treaty override.

A detailed breakdown of the relevant information is in the table below.

Table 1: Slovak tax treaties detailed breakdown

\begin{tabular}{|c|c|c|}
\hline & Number & Countries \\
\hline $\begin{array}{l}\text { Double tax treaties } \\
\text { concluded before the } \\
\text { OECD Commentary } \\
(2003)\end{array}$ & 47 & $\begin{array}{l}\text { Australia, Austria, Belgium*76, Belarus, Bosnia } \\
\text { and Herzegovina, Brazil, Bulgaria, Canada*, } \\
\text { Croatia, Cyprus, China, Denmark, Finland, France, } \\
\text { Greece, Germany, Hungary, India, Indonesia, } \\
\text { Ireland, Italy, Israel, Japan, Lithuania, Latvia, } \\
\text { Luxemburg, Malta, Mongolia, Montenegro, } \\
\text { Netherlands*, Nigeria, Norway, Poland, Republic } \\
\text { of South Africa. Romania, Russia, Serbia, Sri } \\
\text { Lanka, Spain, Switzerland*, Sweden, Tunisia, } \\
\text { Turkey, Turkmenistan, Ukraine, United Kingdom } \\
\text { of Great Britain and Northern Ireland, USA }\end{array}$ \\
\hline $\begin{array}{l}\text { Double tax treaties } \\
\text { concluded after the } \\
\text { OECD Commentary } \\
(2003)\end{array}$ & 18 & $\begin{array}{l}\text { Czech Republic, Estonia, Georgia, Iceland, Kuwait, } \\
\text { Kazakhstan, Korea, Libya, Macedonia, Mexico, } \\
\text { Moldova, Portugal, Slovenia, Singapore, Syria, } \\
\text { Taiwan, Uzbekistan, Vietnam }\end{array}$ \\
\hline $\begin{array}{l}\text { Double tax treaties with } \\
\text { a limitation on benefits } \\
\text { or principal purpose test } \\
\text { provision (i.e. GAAR } \\
\text { equivalent) }\end{array}$ & 4 & Cyprus, Israel, Poland, USA \\
\hline $\begin{array}{l}\text { Double tax treaties with } \\
\text { reference to the } \\
\text { prevention of tax } \\
\text { evasion in its title or } \\
\text { preamble }\end{array}$ & $\begin{array}{c}50 \\
31 \text { before } \\
2003\end{array}$ & $\begin{array}{l}\text { Australia, Belgium, Belarus, Brazil, Bulgaria, } \\
\text { Canada, Cyprus, Czech Republic, China, } \\
\text { Estonia, Finland, Greece, Georgia, Hungary, } \\
\text { India, Indonesia, Ireland, Iceland, Italy, Israel, } \\
\text { Kazakhstan, Korea, Kuwait, Lithuania, Libya, } \\
\text { Latvia, Luxemburg, Macedonia, Malta, Mexico, } \\
\text { Moldova, Netherlands, Nigeria, Norway, Poland, } \\
\text { Portugal, Republic of South Africa, Romania, } \\
\text { Slovenia, Singapore, Sri Lanka, Syria, Spain, } \\
\text { Taiwan, Tunisia, Turkey, Ukraine, USA, } \\
\text { Uzbekistan, Vietnam }\end{array}$ \\
\hline
\end{tabular}

Continued on next page

\footnotetext{
${ }^{75}$ Other specific anti-abuse rules could be found in several other treaties in provisions regarding the - permanent establishment, beneficial ownership, artiste companies, etc. Their analysis is beyond the scope of this article. $76 *$ In the case of these states, the initial double tax treaty was concluded before 2003 and their updates after 2003.
} 


\begin{tabular}{|c|c|c|}
\hline & Number & Countries \\
\hline $\begin{array}{l}\text { Double tax treaties } \\
\text { concluded before the } \\
\text { OECD Commentary } \\
\text { (2003) with no } \\
\text { limitation on benefits or } \\
\text { principal purpose test } \\
\text { provisions (i.e. GAAR } \\
\text { equivalent) }\end{array}$ & 43 & $\begin{array}{l}\text { Australia, Austria, Belgium, Belarus, Bosnia and } \\
\text { Herzegovina, Brazil, Bulgaria, Canada, Croatia, } \\
\text { China, Denmark, Finland, France, Greece, } \\
\text { Germany, Hungary, India, Indonesia, Ireland, Italy, } \\
\text { Japan, Lithuania, Latvia, Luxemburg, Malta, } \\
\text { Mongolia, Montenegro, Netherlands, Nigeria, } \\
\text { Norway, Republic of South Africa, Romania, } \\
\text { Russia, Serbia, Sri Lanka, Spain, Switzerland, } \\
\text { Sweden, Tunisia, Turkey, Turkmenistan, Ukraine, } \\
\text { United Kingdom of Great Britain, and Northern } \\
\text { Ireland }\end{array}$ \\
\hline
\end{tabular}

Source: own analysis

\section{Conclusion}

From the above, it is clear that a GAAR would in general have very limited effectiveness in tackling tax treaty abuse situations, as in a majority of cases its application would result in treaty override. This is particularly relevant in the Slovak Republic, but also in other states applying a monistic approach to international treaties, as the respective taxpayer affected by such treaty override application of GAAR would have a direct redress to local courts. In the Slovak context in particular, the majority of the arguments favouring the application of domestic anti-abuse rules in tax treaty situations are not applicable, as (a) it seems that the Slovak courts will be reluctant to apply an ambulatory approach to interpretation of the OECD Commentary and (b) Slovakia has a relatively large catalogue of "old" treaties dating from before 2003 , i.e. the year in which the approach of OECD towards treaty abuse shifted dramatically.

For the moment, the best policy advice seems to be that Slovak tax administration should use alternatives to GAAR that do not result in treaty override ${ }^{77}$ and for the Slovak government to actively push for a timely ratification of the multilateral instrument ${ }^{78}$. In the meantime, the Slovak government might engage in discussions with its existing treaty partners to amend its old treaties in line with the recommendation of the European Commission, which encourages the insertion into the concluded tax treaties of Member states the modification of GAAR in the sense: "benefit under the Convention (tax treaty) shall not be granted if its obtaining was one of the principal purposes, unless it reflects a genuine economic activity or that granting that benefit in these circumstances would be in accordance with the object and purpose of the relevant provisions of this Convention" ${ }^{79}$

\footnotetext{
77 Krever (2016).

${ }^{78}$ The multilateral instrument, formally the Multilateral Convention to Implement Tax Treaty Related Measures to Prevent Base Erosion and Profit Shifting, was signed on 7 June 2017 by the first 70 signatories. It has not been ratified yet. See further OECD (2015c) and European Commission (2016) which proposes "the inclusion in the multilateral instrument (BEPS action 15) of a general anti-abuse rule based on a 'principal purpose test' (PPT) of transactions or arrangements [which] needs to be aligned with the case law of the Court of Justice of the European Union as regards the abuse of law".

${ }^{79}$ European Commission (2016).
} 
Finally, as some of the old tax treaties are also subject to the dualist approach, the Slovak government might alter the respective provisions of local Slovak laws, giving such treaties general priority so that this priority is subject to local anti-abuse rules or, alternatively, amending the Slovak GAAR to expressly read that it will apply notwithstanding the provisions of tax treaty. ${ }^{80}$

\section{Acknowledgements}

Supported by the Slovak Research and Development Agency (APVV) Grant APVV-160499.

\section{References}

Adame, L. (2016). Slovak Republic. In Staringer et al. (eds.). GAARs - a key element of tax systems in the post-BEPS tax world. Amsterdam: IBFD.

Aust, A. (2013). Modern treaty law and practice. Cambridge: Cambridge University Press. Blahova, R. (2014). Slovak Regional Court on a Dutch Holding without sufficient substance. In Lang, M. et al (eds.). Tax Treaty Case Law Around the Globe 2013. Vienna: Linde.

Bothe, M. (1980). Legal and Non-Legal Norms - a meaningful distinction in international relations? Netherlands Yearbook of International Law, 11, 65-95.

Cloer, A., Hagemann, T. (2016). Constitutionality of Treaty Override. European taxation, 56(7).

Cotrut, M. (ed.) (2015). International Tax Structures in the BEPS Era: An Analysis of Anti-Abuse Measures. Amsterdam: IBFD.

European Commission. (2012). Commission Recommendation of 6.12.2012 on aggressive tax planning, C (2012) 8806 final, Brussels 6.12.2012.

European Commission. (2016). Commission Recommendation of 28.1.2016 on the implementation of measures against tax treaty abuse, COM(2016) 271 final.

Freedman, J. (2016). United Kingdom. In. Staringer et al. (eds.). GAARs - a key element of tax systems in the post-BEPS tax world. Amsterdam: IBFD.

Gerzova, L., Popa, O. (2013). Compatibility of Domestic Anti-Avoidance Measures with Tax Treaties. European taxation, 53(9).

Holmes, K. (2014). International Tax Policy and Double Tax Treaties (2nd ed.). Amsterdam: IBFD.

Jimenéz, A. J. M. (2004). The 2003 revision of the OECD commentaries on the improper use of tax treaties: a case for the declining effect of the OECD commentaries? Bulletin for international fiscal documentation, 58(1), 17-30.

Krever, R. (2016). General Report: GAARs. In Staringer et al. (eds.). GAARs - a key element of tax systems in the post-BEPS tax world. Amsterdam: IBFD.

Kubicová, J., Záhumenská, M. (2016). The Relationship between Taxation and Bilateral Investment Agreements - Case of the Slovak Republic. International Journal of Research in Business Studies and Management, 3(1), 9-22.

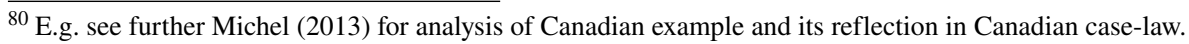


Kulcsár, T., Rogers-Glabush, J. (2013). Treaty Override: Reviving a Long-Forgotten Debate in the Name of Anti-Avoidance. European taxation, 53(9), 411-413.

Kulcsár, T. (2012). The application of general anti-abuse rules (GAARs) under double tax agreements. IBFD White papers. Amsterdam: IBFD.

Lang, M. (2014). Introduction to the law of double taxation conventions. Vienna: Linde Verlag GmbH.

Lantajová, D., Jankuv, J., Kušlita, J. (2011). Slovakia. In: Shelton, D. (ed.). International Law and Domestic Legal Systems: Incorporation, Transformation and Persuasion. New York: Oxford University Press.

Larking, B. (ed.) (2005). International Tax Glossary. (5th ed.). Amsterdam: IBFD.

Maisto, G. (ed.) (2006). Tax treaties and domestic law. Amsterdam: IBFD.

Michel, B. (2013). Anti-Avoidance and Tax Treaty Override: Pacta Sunt Servata? European taxation, 53(9).

Mikic, M. (2013). Selective Bibliography on Tax Treaty Override. European taxation, 53(9).

Murray, R. (2012). Tax Avoidance. London: Sweet and Maxwell.

New Zealand Inland Revenue. (2016). Relationship between double tax agreements and anti-avoidance rules. Retrieved August 11, 2016, from http://taxpolicy.ird.govt.nz/publications/2016-ris-archcrm-bill/relationship-between-dtas-and-anti-avoidance-rules.

OECD. (2003). OECD Model Tax Convention on Income and on Capital. Paris: OECD Publishing.

OECD. (2015). Model Tax Convention on Income and on Capital 2014 (Full Version). Paris: OECD Publishing.

OECD. (2015a). R(8). Tax treaty override. In OECD Model Tax Convention on Income and on Capital 2014 (Full Version). Paris: OECD Publishing.

OECD. (2015b). R(6). Double taxation conventions and the use of conduit companies. In OECD Model Tax Convention on Income and on Capital 2014 (Full Version). Paris : OECD Publishing.

OECD. (2015c). Developing a Multilateral Instrument to Modify Bilateral Tax Treaties, Action 15 - 2015 Final Report. Paris: OECD Publishing.

Offermanns, R. H. M. J. (2013). Restrictions on Treaty Override Resulting from EU Law. European taxation, 53(9).

Ottová, E. (2006). Teória práva. Šamorín: Heuréka.

Russo, R. et al. (2010). Fundamentals of International Tax Planning. Amsterdam: IBFD. Sachdeva, S. (2013). Tax Treaty Overrides: A Comparative Study of the Monist and the Dualist Approaches. Intertax, 41(4), 180-207.

Sasseville, J. A. (2006). Tax Treaty Perspective: Special Issues. In Maisto, G. (ed.). Tax treaties and domestic law. Amsterdam: IBFD.

Slovak Supreme Court. (2012). Decision of the Supreme Court of the Slovak Republic No. 2Sžf/18/2012 dated 23 October 2012, case Slovenský plynárenský priemysel, a.s. vs Finančné riaditelstvo Slovenskej republiky. Retrieved August 31, 2016, from http://www.supcourt.gov.sk/data/att/28558_subor.pdf. 
Slovak Supreme Court. (2015). Decision of the Supreme Court of the Slovak Republic No. 2Š̆f/76/2014 dated 15 April 2015, case Slovenský plynárenský priemysel, a.s. vs Finančné riaditelstvo Slovenskej republiky. Retrieved August 31, 2016, from http://www.nssr.gov.sk/ data/att/42113_subor.pdf.

Snyder, F. (1994). Soft law and institutional practice in the European Community. In Martin, S. (ed.) The construction of Europe. Netherlands: Springer.

Staringer, C. et al. (eds.) (2016). GAARs - a key element of tax systems in the post-BEPS tax world. Amsterdam: IBFD.

Tax Procedural Code - Act No. 563/2009 Coll. On Administration of Taxes.

Tooma, R. A. (2008). Legislating against Tax Avoidance. Amsterdam: IBFD.

United Nations Model Double Taxation Convention between Developed and Developing Countries.

Vienna Convention on the law of treaties concluded at Vienna on 23 May 1969.

Vogel, K. (1997). Klaus Vogel on Double Taxation Conventions: A Commentary. Kluwer law international.

Wattel, P. J. et al. (2003) The legal status of the OECD commentary and static or ambulatory interpretation of tax treaties. European Taxation, 43(7), 222-235.

Zemanek, K. Buffard, I. (1998). The "Object and Purpose" of a Treaty: An Enigma. Austrian Review of International \& European Law, 3. 